\title{
The Antioxidant Properties of Selenium and Vitamin E; Their Role in Periparturient Dairy Cattle Health Regulation
}

\author{
Jianxin Xiao ${ }^{1,+} \mathbb{D}$, Muhammad Zahoor Khan ${ }^{1,2,+} \mathbb{D}$, Yulin Ma ${ }^{1}$, Gibson Maswayi Alugongo ${ }^{1}\left(\mathbb{D}\right.$, Jiaying Ma $^{1}$, \\ Tianyu Chen ${ }^{1}$, Adnan Khan ${ }^{3}$ (D) and Zhijun Cao ${ }^{1, *(\mathbb{D})}$
}

1 Beijing Engineering Technology Research Center of Raw Milk Quality and Safety Control, State Key Laboratory of Animal Nutrition, College of Animal Science and Technology, China Agricultural University, Beijing 100193, China; xiaojianxin-dairy@cau.edu.cn (J.X.); zahoorcau@cau.edu.cn (M.Z.K.); bs20193040395@cau.edu.cn (Y.M.); bh2020270153@cau.edu.cn (G.M.A.); majiaying@cau.edu.cn (J.M.); chentianyu@cau.edu.cn (T.C.)

2 Faculty of Veterinary and Animal Sciences, The University of Agriculture, Dera Ismail Khan 29050, Pakistan

3 Shenzhen Branch, Guangdong Laboratory for Lingnan Modern Agriculture, Genome Analysis Laboratory of the Ministry of Agriculture, Agricultural Genomics Institute at Shenzhen, Chinese Academy of Agricultural Sciences, Shenzhen 518000, China; dr.adnan93@cau.edu.cn

* Correspondence: caozhijun@cau.edu.cn; Tel.: +86-10-62733746

+ Authors equally contributed to this work.

check for

updates

Citation: Xiao, J.; Khan, M.Z.; Ma, Y.; Alugongo, G.M.; Ma, J.; Chen, T.; Khan, A.; Cao, Z. The Antioxidant Properties of Selenium and Vitamin E; Their Role in Periparturient Dairy Cattle Health Regulation. Antioxidants 2021, 10, 1555. https:// doi.org/10.3390/antiox10101555

Academic Editor:

Alessandra Napolitano

Received: 30 July 2021

Accepted: 27 September 2021

Published: 29 September 2021

Publisher's Note: MDPI stays neutral with regard to jurisdictional claims in published maps and institutional affiliations.

Copyright: (c) 2021 by the authors. Licensee MDPI, Basel, Switzerland. This article is an open access article distributed under the terms and conditions of the Creative Commons Attribution (CC BY) license (https:// creativecommons.org/licenses/by/ $4.0 /)$.
Abstract: Dairy cattle experience health risks during the periparturient period. The continuous overproduction of reactive oxygen species (ROS) during the transition from late gestation to peak lactation leads to the development of oxidative stress. Oxidative stress is usually considered the main contributor to several diseases such as retained placenta, fatty liver, ketosis, mastitis and metritis in periparturient dairy cattle. The oxidative stress is generally balanced by the naturally available antioxidant system in the body of dairy cattle. However, in some special conditions, such as the peripariparturient period, the natural antioxidant system of a body is not able to balance the ROS production. To cope with this situation, the antioxidants are supplied to the dairy cattle from external sources. Natural antioxidants such as selenium and vitamin E have been found to restore normal health by minimizing the harmful effects of excessive ROS production. The deficiencies of Se and vitamin $\mathrm{E}$ have been reported to be associated with various diseases in periparturient dairy cattle. Thus in the current review, we highlight the new insights into the Se and vitamin E supplementation as antioxidant agents in the health regulation of periparturient dairy cattle.

Keywords: periparturient period; dairy cattle; oxidative stress; antioxidants; selenium; vitamin E

\section{Introduction}

The antioxidant system's capacity to neutralize and remove reactive oxygen species (ROS) created during metabolic activities is normally sufficient under normal physiological conditions. It has been documented that metabolic changes during pregnancy and calving may raise ROS production beyond the required threshold [1]. Oxidative stress developed when the imbalance between ROS production and the availability of antioxidant molecules occurred, which had proven cattle to various infections [2,3]. The high production of ROS other than the normal level causes lipid peroxidation results in oxidative stress, tissue damage and altering the level of reduced glutathione (GSH), which is involved in glutathione metabolism $[4,5]$. Damage to the structure and function of cellular macromolecules (lipids, proteins, and nucleic acids) occurs when the pro/antioxidant balance is disrupted, resulting in oxidative stress and a preponderance of oxidation over reduction processes lead to metabolic disorders and diseases in dairy cows [6]. Thus maintaining redox homeostasis in dairy cows is crucial during the periparturient and peak lactation phases [7-9].

The oxidative stress around parturition may contribute to immune and inflammatory abnormal function and thus increase the chances of metabolic and infectious diseases [10,11]. 
The balance between oxidants and antioxidants is necessary during the milking period to improve dairy cows' efficiency [12]. During the periparturient period, oxidative stress is considered one of the key factors associated with susceptibility to infections such as retained fetal membranes, metritis, mammary edema, mastitis and retained fetal membranes [2,13], which is supported by several studies [14-16]. Harrison et al. reported that oxidative stress before parturition is probably the main contributing factor for metabolic and reproductive disorders in the milking period in dairy cattle [17]. Consistently Kizil et al. documented that the acceleration of peroxidation reactions and weakened antioxidant system in cows were associated with metritis [18].

The supplementation of vitamins and minerals has been documented to have a positive impact on the enhancement of the antioxidant status and immune responses in perinatal calves [19]. The multicomponent antioxidative system neutralized the generated ROS, including selenium-dependent glutathione as one of its primary components (GSH-Px; EC 1.11.1.9). The catalytic center of the enzyme contains selenium in the form of selenocysteine, which catalyzes the reduction of hydrogen peroxide and lipid peroxides when combined with GSH [20]. Consistently, the Se and vitamin E have been widely studied for their antioxidative properties and immune regulation and consequent role in cattle health [21-23]. Similarly, other studies also documented the positive impact of Se and vitamin E supplementation on the antioxidant and health status improvement of dairy cattle $[24,25]$. Consistently, it has been documented that Se and vitamin E administration significantly enhanced the growth rate of calves by reducing the perinatal oxidative stress [26].

The periparturient phase in high milking cows requires maximum antioxidant system efficiency, while deficiency of nutrients like selenium and vitamin E expose dairy cattle to placental retention and mastitis [27]. When the milk yield of cow is high, the antioxidant system's lowering capability of oxidative stress may be insufficient, which is especially obvious in selenium insufficiency. The availability of selenium in the body is the primary determinant of glutathione peroxidase and other selenoproteins involved in various metabolic processes [28-30]. Beside, the deficiency of Se and vitamin E also compromised the immune system of periparturient cows. Vitamin $\mathrm{E}$ and Se share common biological activities have shown antioxidant properties and deficiencies of these nutrients may lead to neutrophil activity reduction as well. Thus, the deficiencies of either one or both may affect the antioxidant activity of the body which is not sufficient to protect the neutrophil from the destructive action of toxic oxygen molecules in mammary glands [31,32]. The sufficient supply of vitamin $\mathrm{E}$ and Se maintained the optimum level of antioxidant activity which is associated with the rapid neutrophil influx into milk during intramammary infection caused by microorganisms [33,34]. Thus, we designed the current review to highlight the consequences of oxidative stress in periparturient dairy cattle and the role of Se and vitamin E supplementation as antioxidant agents in animal health regulation.

\section{Factors That Predispose Periparturient Dairy Cattle to Oxidative Stress}

During the periparturient period, dairy cattle experience several physiological changes [35]. Metabolic stress is one of the key issues developed due to these physiological changes, which are associated with excessive lipid mobilization followed by oxidative stress and inflammatory and immune dysfunction [36,37]. These three processes (excessive mobilization of lipid, oxidative stress, inflammatory and immune dysfunction) are interconnected, which may contribute to the diseases during the periparturient period in dairy cattle [38-41]. The interrelation of oxidative stress, excessive lipid mobilization and inflammatory and immune dysfunction are summarized in Figure 1. 


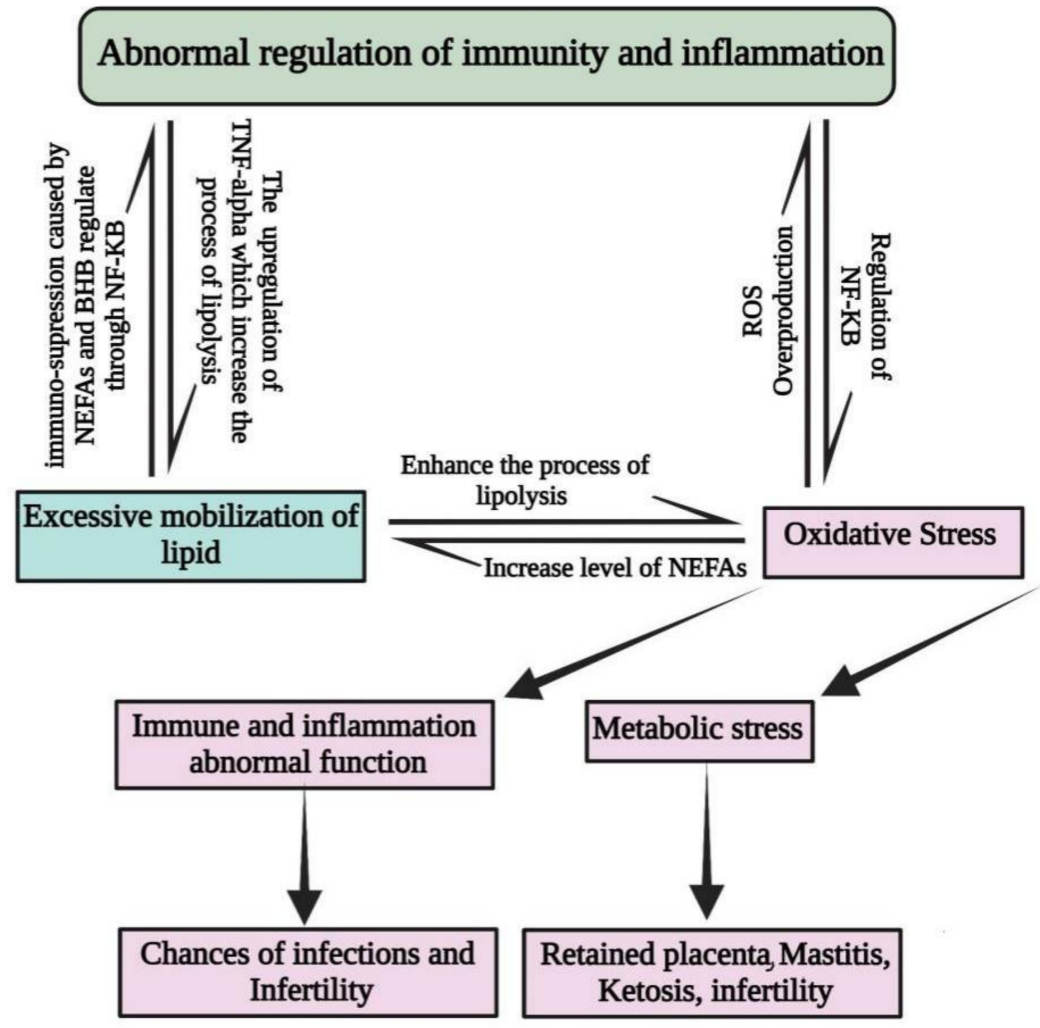

Figure 1. The interconnection among oxidative stress, excessive mobilization of lipid and abnormal regulation of immunity and inflammation; the oxidative stress causes dysfunction of immunity and inflammation by using nuclear factor kappa-B (NF-kB) signaling. The abnormal regulations of inflammation enhance the tumor necrosis factor-alpha production in non-phagocytic cells, resulting in over-production of OS and excessive lipolysis.

The dry matter intake in periparturient dairy cattle decreases and the energy and the calcium requirements increase for lactation [42]. In such condition, more oxygen is utilized by dairy cattle for cellular respiration to fulfill the demand of energy for the onset of lactation, which may lead to a negative energy balance [43]. To fulfill the requirement of energy, dairy cattle utilize body reserves especially in adipose tissues [39]. The increase in the ROS generation and reactive nitrogen species (RNS) may take place in response to excessive lipid mobilization [44,45]. The high intake of crude protein (CP) near parturition in dairy cattle may lead to increased urea level, which is associated with the development of nitrosative stress status, which negatively impacts animal health [44].

The body condition score (BCS) is another important factor determining cows' susceptibility to OS during the periparturient period. It has been documented that cows with higher body condition scores $>3.5 / 5$ were more prone to OS and metabolic stress at transition time [14]. The BCS is characterized by a breakdown of fat and protein followed by catabolic pathways associated with energy production from lipids and amino acids during the transition period in cattle. Furthermore, it has been shown that lipid peroxidation is considered a key factor for OS [46]. The excessive loss in BCS is also a critical factor associated with excessive production of OS and non-esterified fatty acids (NEFAs) in periparturient dairy cattle $[47,48]$.

The increased level of NEFAs and beta-hydroxybutyrate (BHB) due to lipid mobilization may lead to oxidative stress and dysregulation of the immune system in periparturient dairy cattle $[39,49]$. A low level of glucose around parturition is also a critical factor that causes less effective pathogen-killing oxidative burst from polymorphonuclear neutrophils [50] which impaired the host defense. The inflammation around peripartal helps to facilitate the process of parturition and homeorhetic adaptations to the onset of lac- 
tation [51,52]; however the abnormal regulation of inflammation caused by OS around parturition was documented to be associated with metabolic and infectious diseases [39]. From the above discussion we concluded that nutritional management might be one of the effective ways to enhance the antioxidant capacity of animal and protect them from oxidative stress.

\section{Antioxidant Properties of Selenium and Their Role in Dairy Cattle Health}

For animals, there are two important sources of Se: (1) selenoamino acids naturally derived from plants, such as selenomethionine and selenocysteine; and (2) inorganic Se, such as selenate or selenite [53]. Even if an animal's physiological requirement for Se is modest, the anti-oxidant system is weakened if it is not satisfied, resulting in negative repercussions for animal health [54]. Selenium is an essential trace element having antioxidants and immunomodulating properties [55-57].

Dietary selenium (Se) can be supplemented from organic or inorganic sources and this may affect Se metabolism and functional outcome such as antioxidative status and immune functions in dairy cows [53]. Glutathione peroxidase (GPx) is a selenium-containing antioxidant enzyme that plays an important role in the antioxidant defense of the body [58]. The selenium status is usually determined by measuring the level GPx in blood [59]. Furthermore, selenium supplementation caused an undefined antibacterial activity in milk lactoserum [60], but the mechanism of this antibacterial activity is unknown; however, increased glutathione peroxidase (GSH-Px) activity will decrease pathogenic microorganisms' development rate in whey. Selenium is a powerful antioxidant that is integrated into selenate in the form of GSH-Px [61]. GSH-Px is a selenoprotein that plays a role in the antioxidative defense process in mammals and cells. It has the ability to eliminate lipid-damaging peroxides and protect immune cells from oxidative stress [57]. Recently published findings showed that supplementation of $0.30 \mathrm{mg} \mathrm{Se} / \mathrm{kg}$ of DM as Nano-Se for 30 days significantly increased the level of GSH-Px activity. In addition, the mRNA expression of genes (glutathione peroxidase 1, 2 and 4; thioredoxin reductase 2 and 3; and selenoproteins $\mathrm{W}, \mathrm{T}, \mathrm{K}$ and $\mathrm{F}$ ) were upregulated in response to Nano-Se supplementation in mammary glands of dairy cattle [62].

Se regulates several important antioxidant genes such as TOAX, GPX, CAT, SOD, and GSH to relieve oxidative stress [63]. The SOD gene causes the reduction of oxidative stress through the quenching of the superoxide radical and transferring it into less toxic hydrogen peroxide followed by breaks down into water and oxygen to prevent DNA damage using enzyme catalase (CAT) [64-66]. The different types of selenoproteins and their antioxidant properties are summarized in Table 1.

Table 1. Various types of Selenoproteins and their antioxidant properties.

\begin{tabular}{ll}
\hline Selenoproteins & Properties \\
\hline Glutathione peroxidase 1 & Cellular reduction of $\mathrm{H}_{2} \mathrm{O}_{2}[67,68]$. \\
\hline Glutathione peroxidase 2 & Reduction of peroxide in the gut [69]. \\
\hline Glutathione peroxidase 3 & Reduction of peroxide in the blood [70]. \\
\hline Glutathione peroxidase 4 & $\begin{array}{l}\text { Causes the Reduction of hydrogen peroxide radicals and facilitates lipid peroxides to water and } \\
\text { lipid alcohols and the cellular ferroptosis induced by iron [71]. }\end{array}$ \\
\hline Selenoprotein $\mathrm{H}$ & Responsible for Nuclear localization, which is associated with redox sensing and transcription [72,73]. \\
\hline Selenoprotein $\mathrm{O}$ & $\begin{array}{l}\text { Mitochondrial protein consisted of a cytosine-nucleotide-nucleotide-uridine motif suggestive of } \\
\text { the redox role [62]. }\end{array}$ \\
\hline Selenoprotein $\mathrm{T}$ & Deficiency leads to early embryonic lethality [74]. \\
\hline Selenoprotein $\mathrm{W}$ & Have a role of putative antioxidant which is important for muscle growth [75]. \\
\hline Selenophosphate synthetase 2 & $\begin{array}{l}\text { Selenophosphate synthetase 2 has an essential role in the biogenesis of all selenoproteins together } \\
\text { with itself [76]. }\end{array}$ \\
\hline
\end{tabular}


As a food component, selenium is an exceptional agent of protection from atherosclerosis, coronary ischemic disease and cancer. Due to the antioxidant properties, selenium is considered a serious factor of biological and antioxidant protection of vascular endothelium, low-density lipoproteins, DNA protection and chromosomes [77].

\subsection{Selenium Role in Cattle Health}

Oxidative stress is the major contributor to various diseases in dairy cattle, including metabolic and inflammatory problems (mastitis, metritis, ketosis etc.,) [36,78-80], and parasitic infections $[81,82]$. It has been reported that oxidative stress is also associated with reproductive diseases in cattle [83-85]. Furthermore, Diyabalanage et al. reported that an adequate supply of Se is necessary for cattle because it can pass through the placental barrier during pregnancy which is essential for intrauterine and calf development [59]. Consistently, a study reported that the sufficient supply of Se could enhance the antioxidative status and consequent improvement in dairy cattle health [86].

\subsubsection{Selenium Role in Mastitis Control}

High-producing periparturient dairy cows experienced more incidence of mastitis because of oxidative stress which causes the changes in the expression of genes associated with proinflammatory factors [87]. Furthermore, Miranda et al. [88] reported that low levels of Se and glutathione peroxidase activity increase oxidative stress in the mammary gland, which is linked to a reduction in the number of mammary epithelial cells. However, the balance level of Se supplementation decreases the concentration of hydrogen peroxide in mammary epithelial cells [88]. Thus by reducing the level of hydrogen peroxide in mammary epithelial cells, the oxidative status could be relieved which results in reducing the apoptotic cells.

In a recent study GSH-Px activity in whole blood and somatic cell count (SCC) in canned milk have been found to be negatively correlated with each other [89]. The increase in GSH-Px activity in blood after selenium supplementation was linked to a reduction in the frequency of subclinical mastitis in dairy cattle [12]. Consistently, previous studies show that Se supplementation improves antioxidant status; enhances the plasma glutathione peroxidase (GSH-Px) activity, decreases the malondialdehyde (MDA) level in plasma, and decreases SCC in milk [90-94]. The increased level of MDA is an indication of oxidative stress.

Twenty-five selenoproteins have been discovered in animals, and at least 12 of them have a broad immunological and antioxidant role, indicating that they could be useful in dairy cattle udder health and the prevention of subclinical mastitis. The sensitivity of cows' mammary glands to bacteria may be linked to their selenium levels [89]. According to recent studies, the incidence of mammary gland infection in dairy cows is dramatically reduced after eight weeks of selenium supplementation at a dietary level of $0.2 \mathrm{mg} / \mathrm{kg}$ [95]. In general, selenium deficiency suppresses the immune system, whereas supplementing with low amounts of selenium may improve and/or restore immunologic capabilities. In a study, Hemingway found that 14 out of 36 cows receiving antibiotic therapy during the dry time developed mastitis, but only four cows out of 36 receiving $4 \mathrm{mg}$ Se during dry milking had mastitis [96]. A study has documented that Se enhanced the immunity of the mammary gland against infection and subsequent control of mastitis [60]. In addition, they showed that the mammary gland's innate and adaptive immune action is improved through cellular and humoral activities in response to Se supplementation.

It has been reported in a recent study that supplementation of Se for 90 days in mice decreased the IL- $1 \beta$, TNF- $\alpha$, pyrin domain-containing protein 3 (NLRP) and caspase-1 expression level in Staphylococcus aureus-infected mice [97]. Moreover, they documented that Se treatment also causes the inhibition of the NF- $\mathrm{KB} /$ MAPK pathway by suppressing NALP3 and attenuate the mastitis caused by $S$. aureus in mice [98-102]. The Se also inhibited the expression of TLR2, myeloid differentiation factor-88 (Myd88), NLRP3, Caspase-recruitment domain (ASC), and Caspase-1 caused by S. aureus in mice RAW 264.7 macrophages fol- 
lowed by suppression of NF- $\mathrm{KB}$ and MAPK signaling pathways [103,104]. Besides, Se also regulates the LR2-related pathways in the mouse mammary gland followed by $S$. aureus infection to suppress the inflammatory and control mastitis. Injectable $\mathrm{Na}$-selenite as Se also decreased the level of somatic cell count in milk and enhanced dairy cattle's milk production [105].

\subsubsection{Effect of Selenium on Reproduction of Animals}

It has been reported that oxidative stress severely reduces sperm function while antioxidants such as Se can correct the male infertility factors [106,107]. Besides, the decreased level of selenium is also associated with infertility, anestrous and retained placenta in dairy cattle [108]. The deficiency of selenium is associated with abortions $[109,110]$ and stillbirth [111]. The possible reason for abortion is the insufficient progesterone concentration to maintain the pregnancy. The supplementation of Se has been associated with the improved concentration of progesterone and promotes its postpartum production [110]. Moreover, the incidence of metritis and ovarian cysts [97] and the incidence of retained placenta were decreased in response to Se administration [112]. In addition, the Se also regulates the expression of GPx1 in granulosa cells which has a role of antioxidant during ovarian follicular development [113].

It has been reported that the integrity of the sperm membrane and their fertilizing ability is maintained with proper supplementation of antioxidants [114]. Interestingly, a study has documented that proper administration enhances the antioxidant defense capability of the organism which is associated with modulation of the quality of the male ejaculate [115]. Selenoproteins such as selenophosphate synthase (SPS-2) and mitochondrial capsule selenoprotein (MCSeP) have been identified in testis [116]. The OS increases during pathological conditions and leads to lipid peroxidation which is negatively linked to the fertility potential of spermatozoa $[106,117]$. In addition, the high concentration of polyunsaturated fatty acids (PUFAs) also enhances lipid peroxidation which causes the sperm plasma membrane fluidity and integrity, thus affect the number of spermatozoa and their motility, which is necessary for sperm-oocyte fusion ability [106,117-120]. The OS also caused damage to sperm DNA, which is the main factor that contributes to the transmission of defective paternal DNA to a fetus [121]. The ROS produced malondialdehyde (MDA) from its action on membrane lipids which are mutagenic aldehydic lipid peroxidation products in seminal plasma and can be used as an infertility measurement tool [122,123]. The effect of Se on male sperm functions has been summarized in Figure 2.

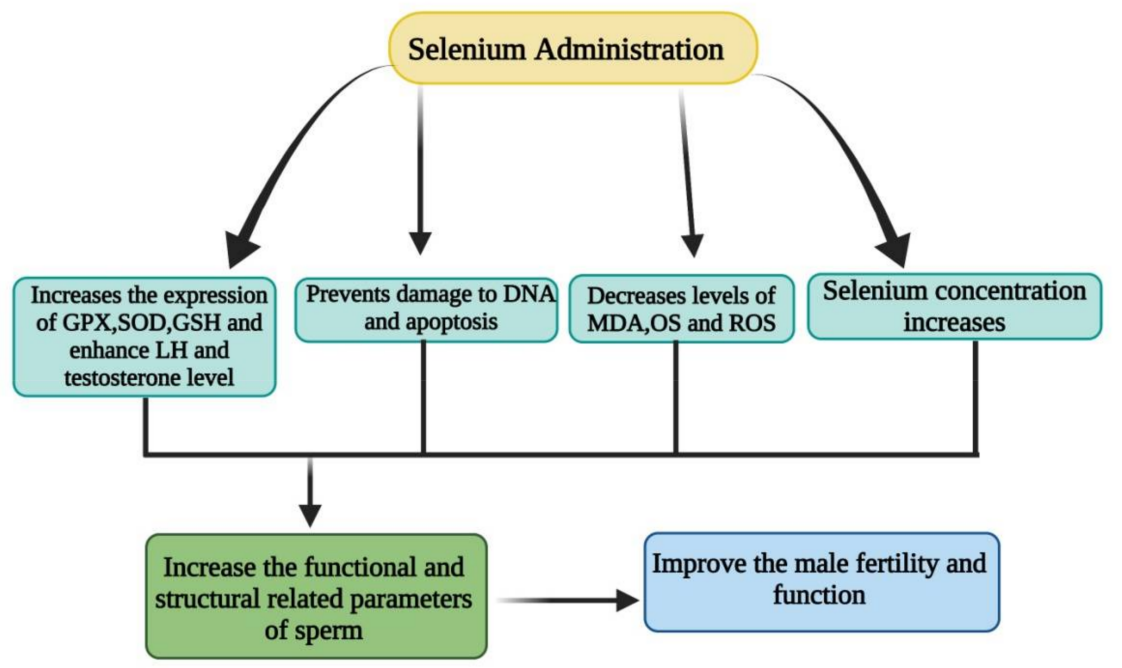

Figure 2. The Se supplementation enhanced the expression of TOAC, GPX, SOD, testosterone and LH; decreased the level of ROS, OS, MDA and consequent DNA damage. The sperm functional and structural parameters are increase and consequent male fertility and reproductive function. 


\subsubsection{Role of Selenium in Ketosis and Fatty Liver Control}

As discussed earlier, negative energy balance and oxidative stress cause many metabolic diseases, including ketosis in periparturient dairy cattle (Figure 1). It is well documented that periparturient cattle utilize their body fat to cope with the negative balance of energy [124]. The fatty acids are considered an essential source of energy in perinatal cattle. Thus, an increase in the concentration of ketone bodies and non-esterified fatty acids in plasma and decrease in blood glucose after delivery can be observed in dairy cattle. These changes may lead to oxidative stress and metabolic diseases like ketosis and fatty liver in dairy cattle $[125,126]$. The decrease in selenium concentration and total antioxidant capacity (TAOC) has been documented in cattle with clinical and subclinical ketosis [127]. Ren et al. has demonstrated that selenium improves glyconeogenesis and enhance the antioxidant system resulting in the reduction in the incidences of metabolic diseases such as fatty liver and kestosis in periparturient dairy cattle [128]. Furthermore, they documented that Se treatment down-regulated the expression of alpha S1 casein (CSN1S1), apolipoprotein A-I (APOA1), apolipoprotein C-II (APOC2) and up-regulated the macrophage-stimulating protein (MST1), chromogranin-A (CGA) in periparturient cattle. It has been documented that down-regulation of APOA1, APOC2, and CNS1S1 is associated with reducing the lipid activity, thus controlling the excessive fat mobilization, thereby reducing the chances of ketosis and fatty liver [129]. Moreover, the oxidized low-density lipoprotein (LDL) oxidation has been inhibited by MST1 which is essential for liver lipid and glucose metabolism [130].

\section{Antioxidant Properties of Vitamin E and Their Role in Dairy Cattle Health}

Vitamin E, a fat-soluble vitamin, is a strong antioxidant agent protecting cell membranes from the lipid peroxidation chain reaction [131] by acting in synergy with Se [132]. The cell membrane of immune cells consists of polyunsaturated fatty acids, which are sensitive to lipid peroxidation by ROS [112]. Exposure to aluminum created oxidative stress in mice, while antioxidative status was restored in mice followed by vitamin $\mathrm{E}$ injection [133]. Vitamin E readily exchanges and equilibrates between lipoproteins [134,135], and being an integral component of lipid membranes, it plays a protective role of lipid membranes from the attack of reactive oxygen [136,137]. It is the chain-breaking antioxidant and the first line of defense against lipid peroxidation, shielding cell membranes from free radical damage [138]. Vitamin E increases the functional efficiency of neutrophils to protect against oxidative damage following the intracellular killing of ingested bacteria [139]. $\alpha$-Tocopherol, the most active form of vitamin $\mathrm{E}$ has been reported in many antioxidative processes $[68,140,141]$. Because of antioxidative property, vitamin $E$ has an impact on the prevention of chronic diseases [142].

The $\alpha$-Tocopherol is the most available bioactive form of vitamin $E$ and has shown strong antioxidative and immunoregulatory properties in dairy cattle [143]. In addition, $\alpha$-tocopherol prevents the proinflammatory status, enhances immunity and is linked to greater energy and reduces the susceptibility to infections in calves [144]. Similarly, Kuhn et al. documented that $\alpha$-tocopherol $(10 \mu M)$ significantly inhibited the loss of bovine mammary endothelial cell barrier integrity induced by pro-oxidant. Furthermore, they reported that $\alpha$-tocopherol has antioxidant properties which effectively prevents the bovine mammary endothelial cell damage and loss of function caused by oxidant challenge [145]. In addition, Mokhber-Dezfouli et al. reported that intramuscular injection of vitamin E significantly decreased the concentration of malondialdehyde (MDA), and lipid peroxidation and increased plasma antioxidant activity $4 \mathrm{hr}$ after birth in calves [146]. The increased level of MDA and decreased level of total antioxidant capacity (TAOC) has been observed around parturition, which shows that the cows were under oxidative stress during the transition period [147]. Vitamin E improves the killing ability of neutrophils [148] and humoral immunity in calves [29], while its deficiency impairs the function of macrophages and neutrophils [149]. It has been documented that Vitamin E supplementation significantly improved the overall performance, energy metabolism and alteration in fat depot mass 
by reducing the oxidative stress in perinatal dairy cows [150]. For ease, the antioxidant properties of vitamin E are summarized in Table 2.

Table 2. The antioxidant properties of vitamin E.

\begin{tabular}{|c|c|c|}
\hline Vitamin E Treatment & Possible Outcomes & References \\
\hline Vitamin E parenteral administration & $\begin{array}{l}\text { Prevented suppression of TAS and GPx } \\
\text { Increased humoral immune response, } \\
\text { Enhanced daily growth in calves }\end{array}$ & [19] \\
\hline $1 \mathrm{mg} / \mathrm{kg}$ of Vitamin E subcutaneous supplement & $\begin{array}{l}\text { Enhance immunity and antioxidant system } \\
\text { Regulated tumor necrosis factor-alpha (TNF- } \alpha) \text {, } \\
\text { interleukin-1 (IL-1), interferon gamma (IFN } \gamma) \text {, SOD and } \\
\text { GPx in calves }\end{array}$ & [22] \\
\hline$\gamma$-tocopherol & $\begin{array}{l}\text { Prevented cellular damage and loss of function of primary } \\
\text { bovine mammary endothelial cells (BMECs) caused by } \\
\text { oxidant challenge } \\
\text { Decreased cell cytotoxicity and enhanced cell viability } \\
\text { Reduced lipid peroxidation and apoptosis caused } \\
\text { oxidative challenge }\end{array}$ & [145] \\
\hline $\begin{array}{l}\text { Vitamin } \mathrm{E} \text { intramuscular injection ( } 40 \mathrm{IU} / \mathrm{kg} \\
\text { body weight) }\end{array}$ & $\begin{array}{l}\text { Enhanced antioxidant activity } \\
\text { Suppressed lipid peroxidation } \\
\text { Decreased MDA values in plasma } \\
\text { Increased } \alpha \text {-tocopherol in plasma of calves }\end{array}$ & [146] \\
\hline Vitamin E supplementation & $\begin{array}{l}\text { Prevented oxidative stress caused by aluminum in rats } \\
\text { Enhanced antioxidative status in rats } \\
\text { Decreased lipid peroxidation } \\
\text { Suppressed MDA concentration in plasma of rats } \\
\text { Decreased Plasma thiobarbituric acid-reacting } \\
\text { substances (TBARS) }\end{array}$ & [133] \\
\hline
\end{tabular}

Enhanced antioxidative status and suppressed oxidative

$\begin{array}{ll}\text { Vitamin E supplementation } & \text { stress in perinatal cattle } \\ & \text { Enhanced GSH-Px concentration }\end{array}$

Decreased the SOD level

Decreased the SOD, MDA and catalase (CAT) level

Enhanced the activity of TAOC, phagocytic activity (PA) of granulocytes and lymphocyte proliferation assay (LPA) in transition dairy cows

Vitamin E supplementation

Enhanced the antioxidant capacity and immunity in transition dairy cattle

Vitamin E supplementation (A review)

\begin{tabular}{|c|c|c|}
\hline Vitamin E supplementation & Reduced tissue peroxidation in chicken & [152] \\
\hline Vitamin E supplementation & $\begin{array}{l}\text { Reduced lipid peroxidation in meat and enhance } \\
\text { antioxidative status }\end{array}$ & [153] \\
\hline Vitamin E supplementation & Enhanced the antioxidative status in dairy cattle & [154] \\
\hline$\alpha$-tocopherol supplementation & $\begin{array}{l}\text { Enhanced antioxidant status } \\
\text { Suppressed lipid peroxidation }\end{array}$ & [155] \\
\hline Vitamin E injection & $\begin{array}{l}\text { Decreased Plasma thiobarbituric acid-reacting substances } \\
\text { (TBARS) in muscle }\end{array}$ & [156] \\
\hline
\end{tabular}

\begin{tabular}{|c|c|c|}
\hline Vitamin E supplementation & Reduced tissue peroxidation in chicken & [152] \\
\hline Vitamin E supplementation & $\begin{array}{l}\text { Reduced lipid peroxidation in meat and enhance } \\
\text { antioxidative status }\end{array}$ & [153] \\
\hline Vitamin E supplementation & Enhanced the antioxidative status in dairy cattle & [154] \\
\hline$\alpha$-tocopherol supplementation & $\begin{array}{l}\text { Enhanced antioxidant status } \\
\text { Suppressed lipid peroxidation }\end{array}$ & [155] \\
\hline Vitamin E injection & $\begin{array}{l}\text { Decreased Plasma thiobarbituric acid-reacting substances } \\
\text { (TBARS) in muscle }\end{array}$ & [156] \\
\hline
\end{tabular}

Vitamin E Role in Cattle Health

A severe decrease in vitamin E level of blood during the transition period in dairy cattle has been observed $[157,158]$. Consequently, it has been investigated that the low level of vitamin $\mathrm{E}$ decreases in plasma during the periparturient period which is associated with intramammary infections [159]. In addition, the dairy cattle having vitamin E concentration in plasma lowers than $3 \mathrm{mg} / \mathrm{mL}$ at calving were more susceptible to 
clinical mastitis [160]. The supplementation of vitamin $\mathrm{E}$ has been documented for its positive effect on antioxidant status; enhance immunity, overall peripartum reproductive performance and energy improvement of transition dairy cows [161]. Thus, vitamin E has gotten a growing interest, especially in preventing mammary infections of perinatal dairy cows [162]. Consistently, previously published studies had reported that vitamin E supplementation during perinatal period could reduce the chances of bovine mastitis $[163,164]$. Moreover, the administration of vitamin E in combination with Se enhanced the immunity and antioxidant status and showed more effective outcomes in preventing intramammary infections $[160,165]$. They further documented that somatic cell counts were significantly reduced in milk in response to vitamin $\mathrm{E}$ and Se treatment, which shows their effectiveness in reducing the incidences of mastitis. Consistently a study has documented that parenteral injections of vitamin E $(2100 \mathrm{mg})$ for two weeks before and on calving day decrease the incidences of mastitis in dairy cows [166]. Similarly, a study documented that supplementation of $\alpha$-Tocopherol ( $1 \mathrm{~g} / \mathrm{cow} /$ day) for 30 days before and up to 60 days after calving significantly increased milk production and reduced the incidence of mastitis in Jersey cattle in India [167]. Vitamin E regulates the immunity and balances the oxidative status which is the main reason that exposes dairy cattle to udder infection and retained placenta [168-170]. Allison and Laven [171] documented that vitamin E is more effective against environmental udder pathogens such as Escherichia coli and Streptococcus uberis which are not normal inhabitants of skin or udder but gain entry during the periparturient period when the teat canals are open in dairy cows. Moreover, vitamin E reduces the oxidative stress in the udder and enhances immunity which usually declines during the transition period in dairy cattle [171].

In addition to antioxidant and immune regulatory properties, vitamin $\mathrm{E}$ also has an essential role in energy metabolism which is also a critical factor that exposes dairy cattle to oxidative stress and consequently to infections $[172,173]$. There is growing evidence that oxidative stress during perinatal period in dairy cows causes metabolism disturbance which may lead to the retained placenta [145]. Oxidative stress and immune disturbances are also considered the common factors that predispose periparturient cows to the retained placenta and consequent fertility issues [174-176]. The incidence of retained placenta was reported to be greater in dairy cattle having deficiency of vitamin E and Se [177]. A deficiency of vitamin $\mathrm{E}$ during the transition period relatively reduces the intake of green fodder, which induces the accumulation of lipid peroxides in the placenta, resulting in retained placenta $[150,178]$. It has been demonstrated that supplementation of a sufficient quantity of vitamin $\mathrm{E}$ in plasma during the periparturient period significantly reduced the cases of retained placenta [179]. Consistently, a study documented that vitamin E injections for seven days significantly reduced the occurrence of retained placenta [178]. Similarly, vitamin E injections $(2100 \mathrm{mg}$ ) for two weeks before and on the day of calving prevent the incidences of retained placenta [154]. Consistently, another study documented that the injection of vitamin E (3000 IU) on the 21st day and the 5th day before parturition may contribute to reducing the incidence of retained placenta in dairy cattle [156]. Another study has shown that presupplementation of vitamin E decreased the incidence of stillbirth and retained placenta and improved the reproductive performance in dairy cattle by reducing oxidative stress [151,179].

\section{Conclusions}

To sum up, redox balance has an essential role in the regulation of several biological processes. However, when the imbalance occurs between the production of oxidants and the animal body natural antioxidant system, it may lead to serious health issues in periparturient dairy cattle. Therefore, the external antioxidant source may contribute to balance the situation of oxidative stress. Vitamin E and Se are well studied for their antioxidant and immune regulating properties. Thus the proper supplementation of Se and vitamin E during the periparturient period could be a good choice to relieve the oxidative stress and the consequent consequences related to health in dairy cattle. 
Author Contributions: Conceptualization, J.X., Y.M., M.Z.K. and Z.C.; writing-original draft preparation, M.Z.K., J.X. and Z.C.; editing and technical review, M.Z.K., J.X., Y.M., G.M.A., A.K., J.M., T.C. and Z.C.; visualization, Z.C.; supervision, Z.C. All authors have read and agreed to the published version of the manuscript.

Funding: The review was supported by the national natural science foundation of China (U20A2062). The funder had no role in the study design, data collection, analysis, decision to publish, and manuscript preparation.

Acknowledgments: We acknowledge the national natural science foundation of China (U20A2062) for their financial support. We also acknowledge the China Agricultural University, Beijing, China, for providing us with an environment of learning. Without this platform, the completion of this work would not have been an easy task.

Conflicts of Interest: The authors declare no conflict of interest.

\section{References}

1. Sordillo, L.M. Factors affecting mammary gland immunity and mastitis susceptibility. Livest. Prod. Sci. 2005, 98, 89-99. [CrossRef]

2. Miller, J.K.; Brzezinska-Slebodzinska, E.; Madsen, F.C. Oxidative stress, antioxidants, and animal function. J. Dairy Sci. 1993, 76, 2812-2823. [CrossRef]

3. Brzezinska-Slebodzinska, E.; Miller, J.K.; Quigley, J.D.; Moore, J.R.; Madsen, F.C. Antioxidant status of dairy cows sup-plemented prepartum with vitamin E and selenium. J. Diary Sci. 1994, 77, 3087-3095. [CrossRef]

4. Wullepit, N.; Raes, K.; Beerda, B.; Veerkamp, R.F.; Fremaut, D.; Smet, S. Influence of management and genetic merit for milk yield on the oxidative status of plasma in heifers. Livest. Sci. 2009, 123, 276-282. [CrossRef]

5. Mikulková, K.; Kadek, R.; Filípek, J. Evaluation of oxidant/antioxidant status, metabolic profile and milk production in cows with metritis. Ir. Vet. J. 2020, 73, 1-11. [CrossRef]

6. Sharma, N.; Singh, N.; Singh, O.; Pandey, V.; Verma, P. Oxidative Stress and Antioxidant Status during Transition Period in Dairy Cows. Asian-Australas. J. Anim. Sci. 2011, 24, 479-484. [CrossRef]

7. Castillo, C.; Hernández, J.; Valverde, I.; Pereira, V.; Sotillo, J.; Alonso, M.L.; Benedito, J.L. Plasma malonaldehyde (MDA) and total antioxidant status (TAS) during lactation in dairy cows. Res. Vet. Sci. 2006, 80, 133-139. [CrossRef] [PubMed]

8. Kowalska, J.; Jankowiak, D. Changes of reduction-oxidation balance in pregnant ruminants. Postepy Biochem. 2009, 55, 323-328.

9. Markiewicz, H.; Gehrke, M.; Malinowski, E.; Kaczmarowski, M. Evaluating the antioxidant potential in the blood of tran-sition cows. Medycyna Weterynaryjna 2005, 61, 1382-1384.

10. Mavangira, V.; Sordillo, L.M. Role of lipid mediators in the regulation of oxidative stress and inflammatory respons-es in dairy cattle. Res. Vet. Sci. 2018, 116, 4-14. [CrossRef] [PubMed]

11. Mavangira, V.M.J.; Mangual, J.C.; Gandy, L.; Sordillo, M. 15-F 2 -Isoprostane concentrations and oxidant status in lac-tating dairy cattle with acute coliform mastitis. J. Vet. Intern. Med. 2016, 30, 339-347. [CrossRef]

12. Sordillo, L.M.; Aitken, S.L. Impact of oxidative stress on the health and immune function of dairy cattle. Vet. Immunol. Immunopathol. 2009, 128, 104-109. [CrossRef] [PubMed]

13. Kankofer, M. Placental Release/Retention in Cows and its Relation to Peroxidative Damage of Macromolecules. Reprod. Domest. Anim. 2002, 37, 27-30. [CrossRef] [PubMed]

14. Bernabucci, U.; Ronchi, B.; Lacetera, N.; Nardone, A. Influence of Body Condition Score on Relationship Between Metabolic Status and Oxidative Stress in Periparturient Dairy Cows. J. Dairy Sci. 2005, 88, 2017-2026. [CrossRef]

15. Castillo, C.; Hernandez, J.; Bravo, A.; López, M.-A.; Pereira, V.; Benedito, J.L. Oxidative status during late pregnancy and early lactation in dairy cows. Vet. J. 2005, 169, 286-292. [CrossRef] [PubMed]

16. Wilde, D. Influence of macro and micro minerals in the peri-parturient period on fertility in dairy cattle. Anim. Reprod. Sci. 2006, 96, 240-249. [CrossRef] [PubMed]

17. Hoedemaker, M.; Prange, D.; Gundelach, Y. Body condition change ante- and postpartum, health and reproductive per-formance in German Holstein cows. Reprod. Domest. Anim. 2010, 44, 167-173. [CrossRef]

18. Kizil, O.; Akar, Y.; Yuksel, M.; Saat, N. Oxidative stress in cows with acute puerperal metritis. Revue Med. Vet. 2010, 161, $353-357$.

19. Mattioli, A.G.; Diana, E.R.; Esteban, T.; Sebastián, J.P.; Santiago, J.R.; Antonio, H.H.M.; Luis, E.F. Effects of Parenteral Supplementation with Minerals and Vitamins on Oxidative Stress and Humoral Immune Response of Weaning Calves. Animals 2020, 10, 1298. [CrossRef]

20. Ottaviano, F.G.; Tang, S.-S.; Handy, D.E.; Loscalzo, J. Regulation of the extracellular antioxidant selenoprotein plasma glutathione peroxidase (GPx-3) in mammalian cells. Mol. Cell. Biochem. 2009, 327, 111-126. [CrossRef]

21. Kegley, E.B.; Ball, J.J.; Beck, P. Impact of mineral and vitamin status on beef cattle immune function and health. J. Anim. Sci. 2016, 94, 59. [CrossRef]

22. Bordignon, R.; Volpato, A.; Glombowsky, P.; Souza, C.F.; Baldissera, M.D.; Secco, R.; Pereira, W.A.B.; Leal, M.L.R.; Vedovatto, M.; Silva, A.S. Nutraceutical effect of vitamins and minerals on performance and immune and antioxidant systems in dairy calves during the nutritional transition period in summer. J. Therm. Biol. 2019, 84, 451-459. [CrossRef] 
23. Teixeira, A.G.V.; Lima, F.S.; Bicalho, M.L.S.; Kussler, A.; Lima, S.F.; Felippe, M.J.; Bicalho, R.C. Effect of an injectable trace mineral supplement containing selenium, copper, zinc, and manganese on immunity, health, and growth of dairy calves. J. Dairy Sci. 2014, 97, 4216-4226. [CrossRef] [PubMed]

24. Abuelo, A.; Alves-Nores, V.; Hernandez, J.; Muiño, R.; Benedito, J.L.; Castillo, C. Effect of parenteral antioxidant supple-mentation during the dry period on postpartum glucose tolerance in dairy cows. J. Vet. Intern. Med. 2016, 30, 892-898. [CrossRef] [PubMed]

25. Cusack, P.; McMeniman, N.; Rabiee, A.; Lean, I. Assessment of the eects of supplementation with vitamin E on health and production of feedlot cattle using meta-analysis. Prev. Vet. Med. 2009, 88, 229-246. [CrossRef]

26. Volpato, A.; Da Silva, A.S.; Crecencio, R.B.; Tomasi, T.; Fortuoso, B.F.; Ribeiro, M.P.; Morsch, V.M.M. A prophylactic protocol to stimulate the immune response also control infectious disease and, consequently, minimizes diarrhea in newborn heifers Microb. Pathog. 2018, 121, 262-268. [CrossRef]

27. Villar, D.; Arthur, J.R.; Gonzalez, J.M. Selenium status in cattle: Interpretation of laboratory results. Bov. Pract. 2002, 36, 73-80.

28. Flohé, J.R.A.L.; Flohé, L.; Andreesen, J.R.; Brigelius, R.-F.; Maiorino, M.; Ursini, F. Selenium, the Element of the Moon, in Life on Earth. IUBMB Life 2000, 49, 411-420. [CrossRef]

29. Rayman, M.P. The importance of selenium to human health. Lancet 2000, 356, 233-241. [CrossRef]

30. Gladyshev, V.N. Selenium in biology and human health: Controversies and perspectives. In Selenium: Its Molecular Biology and Role in Human Health; Hatfield, D.L., Ed.; Springer: Boston, MA, USA, 2001; pp. 313-317.

31. Hoffmann, P.R.; Berry, M.J. The influence of selenium on immune responses. Mol. Nutr. Food Res. 2008, 52, 1273-1280. [CrossRef]

32. Hogan, J.S.; Weiss, W.P.; Smith, K.L. Role of Vitamin E and Selenium in Host Defense Against Mastitis. J. Dairy Sci. 1993, 76, 2795-2803. [CrossRef]

33. Smith, K.L.; Hogan, J.S.; Weiss, W.P. Dietary vitamin E and selenium affect mastitis and milk quality. J. Anim. Sci. 1997, 75, 1659-1665. [CrossRef]

34. Weiss, W.P.; Hogan, J.S.; Todhunter, D.A.; Smith, K.L. Effect of Vitamin E Supplementation in Diets with a Low Concentration of Selenium on Mammary Gland Health of Dairy Cows. J. Dairy Sci. 1997, 80, 1728-1737. [CrossRef]

35. Baumgard, L.H.; Collier, R.J.; Bauman, D.E. A 100-Year Review: Regulation of nutrient partitioning to support lactation. J. Dairy Sci. 2017, 100, 10353-10366. [CrossRef] [PubMed]

36. Sordillo, L.; Mavangira, V. The nexus between nutrient metabolism, oxidative stress and inflammation in transition cows. Anim. Prod. Sci. 2014, 54, 1204-1214. [CrossRef]

37. Abuelo, A.; Joaquín, H.; José, L.B.; Cristina, C. Redox Biology in Transition Periods of Dairy Cattle: Role in the Health of Periparturient and Neonatal Animals. Antioxidants 2019, 8, 20. [CrossRef] [PubMed]

38. Contreras, G.A.; Sordillo, L.M. Lipid mobilization and inflammatory responses during the transition period of dairy cows. Comp. Immunol. Microbiol. Infect. Dis. 2011, 34, 281-289. [CrossRef] [PubMed]

39. Sordillo, L.M.; Raphael, W. Significance of metabolic stress, lipid mobilization, and inflammation on transition cow disor-ders. Vet. Clin. N. Am. Food Anim. Pract. 2013, 29, 267-278. [CrossRef]

40. Hammon, D.S.; Evjen, I.M.; Dhiman, T.R.; Goff, J.P.; Walters, J.L. Neutrophil function and energy status in Holstein cows with uterine health disorders. Vet. Immunol. Immunopathol. 2006, 113, 21-29. [CrossRef]

41. Mittal, M.; Siddiqui, M.R.; Tran, K.; Reddy, S.P.; Malik, A.B. Reactive Oxygen Species in Inflammation and Tissue Injury. Antioxid. Redox Signal. 2014, 20, 1126-1167. [CrossRef]

42. Chapinal, N.; Carson, M.E.; LeBlanc, S.J.; Leslie, K.E.; Godden, S.; Capel, M.; Santos, J.E.; Overton, M.W.; Duffield, T.F. The association of serum metabolites in the transition period with milk production and early-lactation reproductive perfor-mance. J. Dairy Sci. 2012, 95, 1301-1309. [CrossRef]

43. Konvicná, J.; Vargová, M.; Paulíková, I.; Kováč, G.; Kostecká, Z. Oxidative stress and antioxidant status in dairy cows during prepartal and postpartal periods. Acta Vet. Brno 2015, 84, 133-140. [CrossRef]

44. Dalle-Donne, I.; Scaloni, A.; Giustarini, D.; Cavarra, E.; Tell, G.; Lungarella, G.; Colombo, R.; Rossi, R.; Milzani, A. Proteins as biomarkers of oxidative/nitrosative stress in diseases: The contribution of redox proteomics. Mass Spectrom. Rev. 2005, 24, 55-99. [CrossRef] [PubMed]

45. Celi, P.; Gabai, G. Oxidant/Antioxidant Balance in Animal Nutrition and Health: The Role of Protein Oxidation. Front. Vet. Sci. 2015, 2, 48. [CrossRef] [PubMed]

46. Castillo, C.; Hernández, J.; López-Alonso, M.; Miranda, M.; Benedito Luís, J.L. Values of plasma lipid hydroperoxides and total antioxidant status in healthy dairy cows: Preliminary observations. Arch. Anim. Breed. 2003, 46, 227-233. [CrossRef]

47. Contreras, G.A.; Strieder-Barboza, C.; Raphael, W. Adipose tissue lipolysis and remodeling during the transition period of dairy cows. J. Anim. Sci. Biotechnol. 2017, 8, 1-12. [CrossRef] [PubMed]

48. Weber, C.; Hametner, C.; Tuchscherer, A.; Losand, B.; Kanitz, E.; Otten, W.; Singh, S.P.; Bruckmaier, R.M.; Becker, F.; Kanitz, W.; et al. Variation in fat mobilization during early lactation differently affects feed intake, body condition, and lipid and glucose metabolism in high-yielding dairy cows. J. Dairy Sci. 2013, 96, 165-180. [CrossRef]

49. Schönfeld, P.; Wojtczak, L. Fatty acids as modulators of the cellular production of reactive oxygen species. Free Radic. Biol. Med. 2008, 45, 231-241. [CrossRef]

50. Ingvartsen, K.L.; Dewhurst, R.J.; Friggens, N.C. On the relationship between lactational performance and health: Is it yield or metabolic imbalance that cause production diseases in dairy cattle? A position paper. Livest. Prod. Sci. 2003, 83, 277-308. [CrossRef] 
51. Van Engelen, E.; De Groot, M.W.; Breeveld-Dwarkasing, V.N.A.; Everts, M.E.; Van Der Weyden, G.C.; Taverne, M.A.M.; Rutten, V.P. Cervical Ripening and Parturition in Cows are Driven by a Cascade of Pro-Inflammatory Cytokines. Reprod. Domest. Anim. 2009, 44, 834-841. [CrossRef] [PubMed]

52. Farney, J.K.; Mamedova, L.K.; Coetzee, J.F.; KuKanich, B.; Sordillo, L.M.; Stoakes, S.K.; Minton, J.E.; Hollis, L.C.; Bradford, B.J. Anti-inflammatory salicylate treatment alters the metabolic adaptations to lactation in dairy cattle. Am. J. Physiol. Integr. Comp. Physiol. 2013, 305, R110-R117. [CrossRef]

53. Kryukov, G.V.; Castellano, S.; Novoselov, S.V.; Lobanov, A.V.; Zehtab, O.; Guigó, R.; Gladyshev, V.N. Characterization of Mammalian Selenoproteomes. Science 2003, 300, 1439-1443. [CrossRef] [PubMed]

54. Spears, J.W. Micronutrients and immune function in cattle. Proc. Nutr. Soc. 2000, 59, 587-594. [CrossRef] [PubMed]

55. Rhee, S.G.; Chae, H.Z.; Kim, K. Peroxiredoxins: A historical overview and speculative preview of novel mechanisms and emerging concepts in cell signaling. Free Radic. Biol. Med. 2005, 38, 1543-1552. [CrossRef] [PubMed]

56. Hall, J.A.; Bobe, G.; Vorachek, W.R.; Kasper, K.; Traber, M.G.; Mosher, W.D.; Pirelli, G.J.; Gamroth, M. Effect of su-pranutritional organic selenium supplementation on postpartum blood micronutrients, antioxidants, metabolites, and in-flammation biomarkers in selenium-replete dairy cows. Biol. Trace Elem. Res. 2014, 161, 272-287. [CrossRef] [PubMed]

57. Ceballos, A.; Sanchez, J.; Stryhn, H.; Montgomery, J.B.; Barkema, H.W.; Wichtel, J.J. Meta-analysis of the effect of oral selenium supplementation on milk selenium concentration in cattle. J. Dairy Sci. 2009, 92, 324-342. [CrossRef]

58. Pilarczyk, B.; Jankowiak, D.; Tomza-Marciniak, A.; Pilarczyk, R.; Sablik, P.; Drozd, R.; Tylkowska, A.; Skólmowska, M. Selenium Concentration and Glutathione Peroxidase (GSH-Px) Activity in Serum of Cows at Different Stages of Lactation. Biol. Trace Elem. Res. 2012, 147, 91-96. [CrossRef] [PubMed]

59. Diyabalanage, S.; Dangolla, A.; Mallawa, C.; Rajapakse, S.; Chandrajith, R. Bioavailability of selenium (Se) in cattle pop-ulation in Sri Lanka based on qualitative determination of glutathione peroxidase (GSH-Px) activities. Environ. Geochem. Health 2020, 42, 617-624. [CrossRef] [PubMed]

60. Salman, S.; Khol-Parisini, A.; Schafft, H.; Lahrssen-Wiederholt, M.; Hulan, H.W.; Dinse, D.; Zentek, J. The role of dietary selenium in bovine mammary gland health and immune function. Anim. Health Res. Rev. 2009, 10, 21-34. [CrossRef]

61. McGrath, J. Accelerated pre-weaning growth rates in dairy calves: Do antioxidants have a place? Anim. Prod. Sci. 2016, 56, 1275-1284. [CrossRef]

62. Han, S.-J.; Lee, B.C.; Yim, S.H.; Gladyshev, V.N.; Lee, S.-R. Characterization of Mammalian Selenoprotein O: A Redox-Active Mitochondrial Protein. PLoS ONE 2014, 9, e95518. [CrossRef] [PubMed]

63. Chan, J.M.; Darke, A.K.; Penney, K.L.; Tangen, C.M.; Goodman, P.J.; Lee, G.-S.M.; Sun, T.; Peisch, S.; Tinianow, A.M.; Rae, J.M.; et al. Selenium- or Vitamin E-Related Gene Variants, Interaction with Supplementation, and Risk of High-Grade Prostate Cancer in SELECT. Cancer Epidemiol. Biomark. Prev. 2016, 25, 1050-1058. [CrossRef] [PubMed]

64. Fischer, J.L.; Lancia, J.K.; Mathur, A.; Smith, M.L. Selenium protection from DNA damage involves a Ref1/p53/Brca1 protein complex. Anticancer Res. 2006, 26, 899-904. [PubMed]

65. Ahmadi, K.; Roshan-Milani, S.; Asgharzadeh, F.; Pourjabali, M.; Fard, A.A. In Vitro and In Vivo Pretreatment with Selenium Mitigates Tetrahydrocannabinol-Induced Testicular Cell Apoptosis: The Role of AKT and p53 Pathways. Biol. Trace Elem. Res. 2021, 199, 2278-2287. [CrossRef]

66. Lynch, S.J.; Horgan, K.A.; White, B.; Walls, D. Selenium source impacts protection of porcine jejunal epithelial cells from cadmiuminduced DNA damage, with maximum protection exhibited with yeast-derived selenium compounds. Biol. Trace Elem. Res. 2017, 176, 311-320. [CrossRef]

67. Lubos, E.; Loscalzo, J.; Handy, D.E. Glutathione peroxidase-1 in health and disease: From molecular mechanisms to ther-apeutic opportunities. Antioxid. Redox Signal. 2011, 15, 1957-1997. [CrossRef]

68. Li, Y.; Sun, W.G.; Liu, H.K.; Qi, G.Y.; Wang, Q.; Sun, X.R.; Chen, B.Q.; Liu, J.R. $\gamma$-Tocotrienol inhibits angiogene-sis of human umbilical vein endothelial cell induced by cancer cell. J. Nutr. Biochem. 2011, 22, 1127-1136. [CrossRef]

69. Koyama, H.; Omura, K.; Ejima, A.; Kasanuma, Y.; Watanabe, C.; Satoh, H. Separation of selenium-containing proteins in human and mouse plasma using tandem high-performance liquid chromatography columns coupled with inductively coupled plasma-mass spectrometry. Anal. Biochem. 1999, 267, 84-91. [CrossRef]

70. Conrad, M.; Schneider, M.; Seiler, A.; Bornkamm, G.W. Physiological role of phospholipid hydroperoxide glutathione pe-roxidase in mammals. Biol. Chem. 2007, 388, 1019-1025. [CrossRef]

71. Ingold, I.; Berndt, C.; Schmitt, S.; Doll, S.; Poschmann, G.; Buday, K.; Roveri, A.; Peng, X.; Freitas, F.P.; Seibt, T.; et al. Selenium Utilization by GPX4 Is Required to Prevent Hydroperoxide-Induced Ferroptosis. Cell 2018, 172, 409-422. [CrossRef]

72. Panee, J.; Stoytcheva, Z.R.; Liu, W.; Berry, M.J. Selenoprotein H Is a Redox-sensing High Mobility Group Family DNA-binding Protein That Up-regulates Genes Involved in Glutathione Synthesis and Phase II Detoxification. J. Biol. Chem. 2007, 282, 23759-23765. [CrossRef]

73. Novoselov, S.V.; Kryukov, G.V.; Xu, X.-M.; Carlson, B.A.; Hatfield, D.L.; Gladyshev, V.N. Selenoprotein H Is a Nucleolar Thioredoxin-like Protein with a Unique Expression Pattern. J. Biol. Chem. 2007, 282, 11960-11968. [CrossRef]

74. Boukhzar, L.; Hamieh, A.; Cartier, D.; Tanguy, Y.; Alsharif, I.; Castex, M.; Arabo, A.; El Hajji, S.; Bonnet, J.-J.; Errami, M.; et al. Selenoprotein T Exerts an Essential Oxidoreductase Activity That Protects Dopaminergic Neurons in Mouse Models of Parkinson's Disease. Antioxid. Redox Signal. 2016, 24, 557-574. [CrossRef]

75. Jeon, Y.H. Vitamin E, an Antioxidant, as a Possible Therapeutic Agent for Treating Pain. Korean J. Pain 2013, 26, 314-315. [CrossRef] 
76. Xu, X.-M.; Carlson, B.A.; Irons, R.; Mix, H.; Zhong, N.; Gladyshev, V.N.; Hatfield, D.L. Selenophosphate synthetase 2 is essential for selenoprotein biosynthesis. Biochem. J. 2007, 404, 115-120. [CrossRef] [PubMed]

77. Hosnedlova, B.; Marta, K.; Sylvie, S.; Carlos, F.; Branislav, R.; Thembinkosi, D.M.; Jiri, S.; Mojmir, B. A Summary of New Findings on the Biological Effects of Selenium in Selected Animal Species-A Critical Review. Int. J. Mol. Sci. 2017, 18, 2209. [CrossRef] [PubMed]

78. Li, Y.; Ding, H.Y.; Wang, X.C.; Feng, S.B.; Li, X.B.; Wang, Z.; Liu, G.W.; Li, X.W. An association between the level of oxidative stress and the concentrations of NEFA and BHBA in the plasma of ketotic dairy cows. J. Anim. Physiol. Anim. Nutr. 2016, 100, 844-851. [CrossRef] [PubMed]

79. Jozwik, A.; Krzyzewski, J.; Strzalkowska, N.; Polawska, E.; Bagnicka, E.; Wierzbicka, A.; Niemczuk, K.; Lipinska, P.; Horbanczuk, J.O. Relations between the oxidative status, mastitis, milk quality and disorders of reproductive functions in dairy cows-A review. Anim. Sci. Pap. Rep. 2012, 30, 297-307.

80. Gabai, G.; De Luca, E.; Miotto, G.; Zin, G.; Stefani, A.; Da Dalt, L.; Barberio, A.; Celi, P. Protein Oxidation Biomarkers and Uterine Health in Dairy Cows during the Postpartum Period. Antioxidants 2019, 8, 21. [CrossRef]

81. Glombowsky, P.; Bottari, N.B.; Klauck, V.; Fávero, J.F.; Soldá, N.M.; Baldissera, M.D.; Perin, G.; Morsch, V.M.; Schetinger, M.R.C.; Stefani, L.M.; et al. Oxidative stress in dairy cows seropositives for Neospora caninum. Comp. Immunol. Microbiol. Infect. Dis. 2017, 54, 34-37. [CrossRef] [PubMed]

82. Da Silva, A.D.; Da Silva, A.S.; Baldissera, M.D.; Schwertz, C.I.; Bottari, N.B.; Carmo, G.M.; Machado, G.; Lucca, N.J.; Henker, L.C.; Piva, M.M.; et al. Oxidative stress in dairy cows naturally infected with the lungworm Dictyocaulus viviparus (Nematoda: Trichostrongyloidea). J. Helminthol. 2017, 91, 462-469. [CrossRef]

83. Lu, J.; Wang, Z.; Cao, J.; Chen, Y.; Dong, Y. A novel and compact review on the role of oxidative stress in female repro-duction. Reprod. Biol. Endocrinol. 2018, 16, 80. [CrossRef]

84. Talukder, S.; Kerrisk, K.L.; Gabai, G.; Celi, P. Role of oxidant-antioxidant balance in reproduction of domestic animals. Anim. Prod. Sci. 2017, 57, 1588. [CrossRef]

85. Agarwal, A.; Gupta, S.; Sekhon, L.; Shah, R. Redox considerations in female reproductive function and assisted repro-duction: From molecular mechanisms to health implications. Antioxid. Redox Signal. 2008, 10, 1375-1403. [CrossRef]

86. Surai, P.F.; Kochish, I.I.; Fisinin, V.I.; Juniper, D.T. Revisiting Oxidative Stress and the Use of Organic Selenium in Dairy Cow Nutrition. Animals 2019, 9, 462. [CrossRef] [PubMed]

87. Aitken, S.L.; Karcher, E.L.; Rezamend, P.; Gandy, J.C.; VandeHaar, M.J.; Capuco, A.V.; Sorgidillo, L.M. Evaluation of an-tioxidant and proinflammatory gene expression in bovine mammary tissue during the periparturient period. J. Dairy Sci. 2009, 92, 589-598. [CrossRef]

88. Miranda, S.; Wang, Y.J.; Purdie, N.G.; Osborne, V.R.; Coomber, B.L.; Cant, J.P. Selenomethionine stimulates expression of glutathione peroxidase 1 and 3 and growth of bovine mammary epithelial cells in primary culture. J. Dairy Sci. 2009, 92, 2670-2683. [CrossRef] [PubMed]

89. Wang, D.; Jia, D.; He, R.; Lian, S.; Wang, J.; Wu, R. Association Between Serum Selenium Level and Subclinical Mastitis in Dairy Cattle. Biol. Trace Elem. Res. 2021, 199, 1389-1396. [CrossRef] [PubMed]

90. Stewart, W.C.G.; Bobe, G.; Pirelli, W.; Mosher, J. Organic and inorganic selenium: III. Ewe and progeny performance. J. Anim. Sci. 2012, 90, 4536-4543.

91. Gong, J.; Ni, L.; Wang, D.; Shi, B.; Yan, S. Effect of dietary organic selenium on milk selenium concentration and antioxidant and immune status in midlactation dairy cows. Livest. Sci. 2014, 170, 84-90. [CrossRef]

92. Gong, J.; Xiao, M. Selenium and antioxidant status in dairy cows at different stages of lactation. Biol. Trace Elem. Res. 2016, 171, 89-93. [CrossRef] [PubMed]

93. Sun, P.; Wang, J.; Liu, W.; Bu, D.P.; Liu, S.J.; Zhang, K.Z. Hydroxy-selenomethionine: A novel organic selenium source that improves antioxidant status and selenium concentrations in milk and plasma of mid-lactation dairy cows. J. Dairy Sci. 2017, 100, 9602-9610. [CrossRef] [PubMed]

94. Juniper, D.T.; Rymer, C.; Briens, M. Bioefficacy of hydroxy-selenomethionine as a selenium supplement in pregnant dairy heifers and on the selenium status of their calves. J. Dairy Sci. 2019, 102, 7000-7010. [CrossRef]

95. Wang, H.; Bi, C.; Wang, Y.; Sun, J.; Meng, X.; Li, J. Selenium ameliorates Staphylococcus aureus-induced inflammation in bovine mammary epithelial cells by inhibiting activation of TLR2, NF-кB and MAPK signaling pathways. BMC Vet. Res. 2018, 14, 197. [CrossRef] [PubMed]

96. Hemingway, R. The influences of dietary selenium and vitamin E intakes on milk somatic cell counts and mastitis in cows. Vet. Res. Commun. 1999, 23, 481-499. [CrossRef]

97. Wei, M.-J.; Wang, Z.-N.; Yang, Y.; Zhang, S.-J.; Tang, H.; Li, H.; Bi, C.-L. Selenium Attenuates, S. aureus-Induced Inflammation by Regulation TLR2 Signaling Pathway and NLRP3 Inflammasome in RAW 264.7 Macrophages. Biol. Trace Elem. Res. 2021, 1-7. [CrossRef]

98. Zhang, Z.B.; Guo, Y.F.; Li, C.Y.; Qiu, C.W.; Guo, M.Y. Selenium influences mmu-miR-155 to inhibit inflammation in Staphylococcus aureus-induced mastitis in mice. Food Funct. 2019, 10, 6543-6555. [CrossRef]

99. Ma, J.; Zhu, S.; Guo, Y.; Hao, M.; Chen, Y.; Wang, Y.; Yang, M.; Chen, J.; Guo, M. Selenium attenuates Staphylococcus aureus mastitis in mice by inhibiting the activation of the NALP3 Inflammasome and NF-кB/MAPK pathway. Biol. Trace Elem. Res. 2019, 191, 159-166. [CrossRef] 
100. Zhang, L.; Zeng, H.W.; Cheng, W.-H. Beneficial and paradoxical roles of selenium at nutritional levels of intake in healthspan and longevity. Free Radic. Biol. Med. 2018, 127, 3-13. [CrossRef]

101. Kim, S.H.; Johnson, V.J.; Shin, T.Y.; Sharma, R.P. Selenium attenuates lipopolysaccharide-induced oxidative stress re-sponses through modulation of p38 MAPK and NF-kappa B signaling pathways. Exp. Biol. Med. 2004, 229, 203-213. [CrossRef]

102. Liu, K.; Ding, T.; Fang, L.; Cui, L.; Li, J.; Meng, X.; Zhu, G.; Qian, C.; Wang, H.; Li, J. Organic Selenium Ameliorates Staphylococcus aureus-Induced Mastitis in Rats by Inhibiting the Activation of NF-kB and MAPK Signaling Path-ways. Front. Vet. Sci. 2020, 7, 443. [CrossRef]

103. Bi, C.L.; Wang, H.; Wang, Y.J.; Sun, J.; Dong, J.S.; Meng, X.; Li, J.J. Selenium inhibits Staphylococcus aureus induced in-flammation by suppressing the activation of the NF-KB and MAPK signaling pathways in RAW264.7 macrophages. Eur. J. Pharmacol. 2016, 780, 159-165. [CrossRef]

104. Vunta, H.; Belda, B.J.; Arner, R.J.; Reddy, C.C.; Heuvel, J.P.V.; Prabhu, K.S. Selenium attenuates pro-inflammatory gene expression in macrophages. Mol. Nutr. Food Res. 2010, 52, 1316-1323. [CrossRef] [PubMed]

105. Petzer, I.M.; Ferreira, G.M. Injectable organic and inorganic selenium in dairy cows-Effects on milk, blood and somatic cell count levels. Onderstepoort J. Vet. Res. 2019, 86, 1-8.

106. Kefer, J.C.; Agarwal, A.; Sabanegh, E. Role of antioxidants in the treatment of male infertility. Int. J. Urol. 2009, 16, 449-457. [CrossRef] [PubMed]

107. Gadallah, K. Role of Antioxidants in the Treatment of Male Infertility. Surg. Med. Open Access J. 2018, 1. [CrossRef]

108. Kommisrud, E.; Østerås, O.; Vatn, T. Blood Selenium Associated with Health and Fertility in Norwegian Dairy Herds. Acta Vet. Scand. 2005, 46, 229-240. [CrossRef] [PubMed]

109. Giadinis, N.D.; Loukopoulos, P.; Petridou, E.J.; Panousis, N.; Konstantoudaki, K.; Filioussis, G.; Tsousis, G.; Brozos, C.; Koutsoumpas, A.T.; Chaintoutis, S.C.; et al. Abortions in three beef cattle herds attributed to selenium deficiency. Pak. Vet. J. 2016, 36, 145-148.

110. Kamada, H. Effects of selenium-rich yeast supplementation on the plasma progesterone levels of postpartum dairy cows. Asian-Australas. J. Anim. Sci. 2017, 30, 347-354. [CrossRef]

111. Uematsu, M.; Kitahara, G.; Sameshima, H.; Osawa, T. Serum selenium and liposoluble vitamins in Japanese Black cows that had stillborn calves. J. Vet. Med. Sci. 2016, 78, 1501-1504. [CrossRef]

112. Spears, J.W.; Weiss, W.P. Role of antioxidants and trace elements in health and immunity of transition dairy cows. Vet. J. 2008, 176, 70-76. [CrossRef] [PubMed]

113. Ceko, M.J.; Hummitzsch, K.; Hatzirodos, N.; Bonner, W.M.; Aitken, J.B.; Russell, D.L.; Lane, M.; Rodgers, R.J.; Harris, H.H. X-ray fluorescence imaging and other analyses identify selenium and GPX1 as important in female reproductive function. Metallomics 2015, 7, 66-77.

114. Surai, P.F. Selenium in Nutrition and Health; Nottingham University Press: Nottingham, UK, 2006; pp. 487-587.

115. Surai, P.F.; Fisinin, V.I. Selenium in Pig Nutrition and Reproduction: Boars and Semen Quality-A Review. Asian-Australas. J. Anim. Sci. 2015, 28, 730-746. [CrossRef] [PubMed]

116. Fairweather-Tait, S.J.; Collings, R.; Hurst, R. Selenium bioavailability: Current knowledge and future research requirements. Am. J. Clin. Nutr. 2010, 91, 1484S-1491S. [CrossRef]

117. Badade, Z.G.; More, K.; Narshetty, J. Oxidative stress adversely affects spermatogenesis in male infertility. Biomed. Res. 2011, 22, 323-328.

118. Brouwers, J.F.; Gadella, B.M. In Situ detection and localization of lipid peroxidation in individual bovine sperm cells. Free Radic. Biol. Med. 2003, 35, 1382-1391. [CrossRef] [PubMed]

119. Cerolini, S.; Maldjian, A.; Surai, P.; Noble, R. Viability, susceptibility to peroxidation and fatty acid composition of boar semen during liquid storage. Anim. Reprod. Sci. 2000, 58, 99-111. [CrossRef]

120. Duru, N.K.; Morshedi, M.; Oehninger, S. Effects of hydrogen peroxide on DNA and plasma membrane integrity of human spermatozoa. Fertil. Steril. 2000, 74, 1200-1207. [CrossRef]

121. Chandra, G.; Aggarwal, A.; Singh, A.; Singh, A.K.; Kumar, M.; Kushwaha, R.; Singh, Y.K. Oxidative stress in sperm bi-ology-A review. Agric. Rev. 2012, 33, 54-61.

122. Tavilani, H.; Goodarzi, M.T.; Vaisi-Raygani, A.; Salimi, S.; Hassanzadeh, T. Activity of antioxidant enzymes in seminal plasma and their relationship with lipid peroxidation of spermatozoa. Int. Braz. J. Urol. 2008, 34, 485-491. [CrossRef]

123. Shang, X.J.; Li, K.; Ye, Z.Q.; Chen, Y.G.; Yu, X.; Huang, Y.F. Analysis of lipid peroxidative levels in seminal plasma of in-fertile men by high-performance liquid chromatography. Arch. Androl. 2004, 50, 411-416. [CrossRef]

124. Sahinduran, S.; Sezer, K.; Büyükoğlu, T.; Albay, M.K.; Karakurum, M.C. Evaluation of Some Haematological and Biochemical Parameters Before and After Treatment in Cows with Ketosis and Comparison of Different Treatment Methods. J. Anim. Vet. Adv. 2010, 9, 266-271. [CrossRef]

125. Katoh, N. Relevance apolipoproteins in the development of fatty liver and fatty liver-related peripartum disease in dairy cows. J. Vet. Med. Sci. 2002, 64, 293-307. [CrossRef]

126. Folnozic, I.; Turk, R.; Đuričić, D.; Vince, S.; Pleadin, J.; Flegar-Meštrić, Z.; Valpotić, H.; Dobranic, T.; Gracner, D.; Samardzija, M. Influence of Body Condition on Serum Metabolic Indicators of Lipid Mobilization and Oxidative Stress in Dairy Cows During the Transition Period. Reprod. Domest. Anim. 2015, 50, 910-917. [CrossRef] 
127. Kozat, S.; Yüksek, N. Evaluation of Total Antioxidant, Total Calcium, Selenium, Insulin, Free Triiodothyronine and Free Thyroxine Levels in Cows with Ketosis. Iran. J. Appl. Anim. Sci. 2017, 7, 393-399.

128. Ren, Z.-H.; Bai, L.-P.; Shen, L.-H.; Luo, Z.-Z.; Zhou, Z.-H.; Zuo, Z.-C.; Ma, X.-P.; Deng, J.-L.; Wang, Y.; Xu, S.-Y.; et al. Comparative iTRAQ Proteomics Reveals Multiple Effects of Selenium Yeast on Dairy Cows in Parturition. Biol. Trace Elem. Res. 2019, 197, 464-474. [CrossRef]

129. He, P.P.; Jiang, T.; Ouyang, X.P.; Liang, Y.Q.; Zou, J.Q.; Wang, Y.; Shen, Q.Q.; Liao, L.; Zheng, X.L. Lipoprotein lipase: Biosynthesis, regulatory factors, and its role in atherosclerosis and other diseases. Clin. Chim. Acta 2018, 480, 126-137. [CrossRef] [PubMed]

130. Wolska, A.; Dunbar, R.L.; Freeman, L.A.; Ueda, M.; Amar, M.J.; Sviridov, D.O.; Remaley, A.T. Apolipoprotein C-II: New findings related to genetics, biochemistry, and role in triglyceride metabolism. Atherosclerosis 2017, 267, 49-60. [CrossRef]

131. Andrieu, S. Is there a role for organic trace element supplements in transition cow health? Vet. J. 2008, 176, 77-83. [CrossRef] [PubMed]

132. Mehdi, Y.; Dufrasne, I. Selenium in Cattle: A Review. Molecules 2016, 21, 545. [CrossRef] [PubMed]

133. El-Demerdash, F.M. Antioxidant effect of vitamin E and selenium on lipid peroxidation, enzyme activities and biochemical parameters in rats exposed to aluminium. J. Trace Elem. Med. Biol. 2004, 18, 113-121. [CrossRef] [PubMed]

134. Sontag, T.J.; Parker, R.S. Influence of major structural features of tocopherols and tocotrienols on their $\omega$-oxidation by tocopherol$\omega$-hydroxylase. J. Lipid Res. 2007, 48, 1090-1098. [CrossRef] [PubMed]

135. Kamal-Eldin, A.; Appelqvist, L.Å. The chemistry and antioxidant properties of tocopherols and tocotrienols. Lipids 1996, 31, 671-701. [CrossRef]

136. Elsasser, T.H.; Kahl, S.; Lebold, K.M.; Traber, M.G.; Shaffer, J.; Li, C.-J.; Block, S. Short-term alpha- or gam-ma-delta-enriched tocopherol oil supplementation differentially affects the expression of proinflammatory mediators: Se-lective impacts on characteristics of protein tyrosine nitration in vivo. Vet. Sci. Dev. 2013, 3, 20-38. [CrossRef]

137. Yoshida, Y.; Niki, E.; Noguchi, N. Comparative study on the action of tocopherols and tocotrienols as antioxidant: Chemical and physical effects. Chem. Phys. Lipids 2003, 123, 63-75. [CrossRef]

138. Jeon, Y.H.; Park, Y.H.; Lee, J.H.; Hong, J.H.; Kim, I.Y. SelenoproteinWenhances skeletal muscle differentiation by inhibiting TAZ binding to 14-3-3 protein. Biochim. Biophys. Acta 2014, 1843, 1356-1364. [CrossRef] [PubMed]

139. Qureshi, Z.I.; Siddiq, M.; Lodhi, L.A.; Muhammad, G.; Jamil, H. Effect of vitamin E-selenium administration during late gestation on productive and reproductive performance in dairy buffaloes and on growth performance of their calves. Pak. Vet. J. 2010, 30, 83-86.

140. Mardones, P.; Rigotti, A. Cellular mechanisms of vitamin e uptake: Relevance in alpha-tocopherolmetabolism and potential implications for disease. J. Nutr. Biochem. 2004, 15, 252-260. [CrossRef]

141. Jiang, Q.; Yin, X.; Lill, M.A.; Danielson, M.L.; Freiser, H.; Huang, J. Long-chain carboxychromanols, metabolites of vitamin E, are potent inhibitors of cyclooxygenases. Proc. Natl. Acad. Sci. USA 2008, 105, 20464-20469. [CrossRef]

142. Tucker, J.; Townsend, D. Alpha-tocopherol: Roles in prevention and therapy of human disease. Biomed. Pharmacother. 2005, 59, 380-387. [CrossRef]

143. Weiss, W.P. A 100-Year Review: From ascorbic acid to zinc-Mineral and vitamin nutrition of dairy cows. J. Dairy Sci. 2017, 100, 10045-10060. [CrossRef]

144. Krueger, L.A.; Beitz, D.C.; Onda, K.; Osman, M.R.; O’Neil, M.; Lei, S.; Wattoo, F.H.; Stuart, R.L.; Tyler, H.D.; Nonnecke, B. Effects of $d$ - $\alpha$-tocopherol and dietary energy on growth and health of preruminant dairy calves. J. Dairy Sci. 2014, 97, 3715-3727. [CrossRef]

145. Kuhn, M.J.; Sordillo, L.M. Vitamin E analogs limit in vitro oxidant damage to bovine mammary endothelial cells. J. Dairy Sci. 2021, 104, 7154-7167. [CrossRef]

146. Mokhber-Dezfouli, M.R.; Rahimikia, E.; Asadi, F.; Nadalian, M.G. The Role of Route of Vitamin E Administration on the Plasma Antioxidant Activity and Lipid Peroxidation in Newborn Calves. Basic Clin. Pharmacol. Toxicol. 2008, 103, 414-418. [CrossRef]

147. Chatterjee, P.N.; Kaur, H.; Panda, N. Effect of Vitamin E Supplementation on Plasma Antioxidant Vitamins and Immunity Status of Crossbred Cows. Asian-Australas. J. Anim. Sci. 2003, 16, 1614-1618. [CrossRef]

148. Smith, K.L.; Weiss, W.P.; Hogan, J.S. Role of vitamin E in optimizing mammary gland health and productivity of dairy cows: The next generation. In Proceedings of the Southwest Nutrition and Management Conference, Phoenix, AZ, USA; $2000 ;$ pp. 1-8.

149. Erickson, K.L.; Medina, E.A.; Hubbard, N.E. Micronutrients and Innate Immunity. J. Infect. Dis. 2000, 182, S5-S10. [CrossRef] [PubMed]

150. Schäfers, S.; Von Soosten, D.; Meyer, U.; Drong, C.; Frahm, J.; Kluess, J.; Raschka, C.; Rehage, J.; Tröscher, A.; Pelletier, W.; et al. Influence of conjugated linoleic acid and vitamin E on performance, energy metabolism, and change of fat depot mass in transitional dairy cows. J. Dairy Sci. 2017, 100, 3193-3208. [CrossRef]

151. Khatti, A.; Mehrotra, S.; Patel, P.K.; Singh, G.; Maurya, V.P.; Mahla, A.S.; Chaudhari, R.K.; Narayanan, K.; Das, G.K.; Singh, M.; et al. Supplementation of vitamin E, selenium and increased energy allowance mitigates transition stress and improves postpartum reproductive performance in crossbred cow. Theriogenology 2017, 104, 142-148. [CrossRef] [PubMed]

152. Guo, Y.; Tang, Q.; Yuan, J.; Jiang, Z. Effects of supplementation with vitamin E on the performance and the tissue perox-idation of broiler chicks and the stability of thigh meat against oxidative deterioration. Anim. Feed Sci. Technol. 2001, 89, 165-173. [CrossRef] 
153. Gallardo, B.; Manca, M.G.; Mantecón, A.R.; Nudda, A.; Manso, T. Effects of linseed oil and natural or synthetic vitamin E supplementation in lactating ewes' diets on meat fatty acid profile and lipid oxidation from their milk fed lambs. Meat Sci. 2015, 102, 79-89. [CrossRef] [PubMed]

154. Santos, N.W.; Yoshimura, E.H.; Machado, E.; Matumoto-Pintro, P.T.; Montanher, P.F.; Visentainer, J.V.; Zeoula, L.M. Antioxidant effects of a propolis extract and vitamin E in blood and milk of dairy cows fed diet containing flaxseed oil. Livest. Sci. 2016, 191, 132-138. [CrossRef]

155. Ripoll, G.; González-Calvo, L.; Molino, F.; Calvo, J.H.; Joy, M. Effects of finishing period length with vitamin e sup-plementation and alfalfa grazing on carcass color and the evolution of meat color and the lipid oxidation of light lambs. Meat Sci. 2013, 93, 906-913. [CrossRef]

156. Maiorano, G.; Cavone, C.; McCormick, R.J.; Ciarlariello, A.; Gambacorta, M.; Manchisi, A. The effect of dietary energy and vitamin E administration on performance and intramuscular collagen properties of lambs. Meat Sci. 2007, 76, 182-188. [CrossRef]

157. Politis, I. Reevaluation of vitamin E supplementation of dairy cows: Bioavailability, animal health and milk quality. Animal 2012, 6, 1427-1434. [CrossRef]

158. Haga, S.; Miyaji, M.; Nakano, M.; Ishizaki, H.; Matsuyama, H.; Katoh, K.; Roh, S. Changes in the expression of $\alpha$-tocopherolrelated genes in liver and mammary gland biopsy specimens of peripartum dairy cows. J. Dairy Sci. 2018, 101, 5277-5293. [CrossRef] [PubMed]

159. Persson, W.K.; Sandgren, H.C.; Emanuelson, U.; Jensen, S.K. Supplementation of RRR-alpha-tocopheryl acetate to per-iparturient dairy cows in commercial herds with high mastitis incidence. J. Dairy Sci. 2007, 90, 3640-3646. [CrossRef]

160. Politis, I.; Bizelis, I.; Tsiaras, A.; Baldi, A. Effect of vitamin E supplementation on neutrophil function, milk composition and plasmin activity in dairy cows in a commercial herd. J. Dairy Res. 2004, 71, 273-278. [CrossRef] [PubMed]

161. Bouwstra, R.J.; Nielen, M.; Stegeman, J.A.; Dobbelaar, P.; Newbold, J.R.; Jansen, E.H.J.M.; Van Werven, T. Vitamin E supplementation during the dry period in dairy cattle. Part I: Adverse effect on incidence of mastitis postpartum in a double-blind randomized field trial. J. Dairy Sci. 2010, 93, 5684-5695. [CrossRef] [PubMed]

162. Pritee, G.; Upadhyay, A.K.; Gangwar, N.K.; Rajput, M.K.S. Relationship of mineral and vitamin supplementation with mastitis. Vet. World 2008, 1, 103-104.

163. Cengiz, M.; Bastan, A. Effectiveness of dry cow therapy antibiotic treatment, internal teat sealant, and a-tocopherol against new intramammary infections in cows. Bull. Vet. Inst. Pulawy. 2015, 59, 71-78. [CrossRef]

164. Sharma, N.; Maiti, S.K. Effect of dietary supplementation of vitamin E and selenium in subclinical mastitis in dairy cows. Indian J. Vet. Med. 2005, 25, 76-79.

165. Morgante, M.; Beghelli, D.; Pauselli, M.; Dall'Ara, P.; Capuccella, M.; Ranucci, S. Effect of Administration of Vitamin E and Selenium During the Dry Period on Mammary Health and Milk Cell Counts in Dairy Ewes. J. Dairy Sci. 1999, 82, 623-631. [CrossRef]

166. Bourne, N.; Wathes, D.C.; Lawrence, K.E.; McGowan, M.; Laven, R.A. The effect of parenteral supplementation of vitamin E with selenium on the health and productivity of dairy cattle in the UK. Vet. J. 2008, 177, 381-387. [CrossRef] [PubMed]

167. Singh, A.K.; Bhakat, C.; Kumari, T.; Mandal, D.K.; Chatterjee, A.; Karunakaran, M.; Dutta, T.K. Influence of pre and postpartum alpha-tocopherol supplementation on milk yield, milk quality and udder health of Jersey crossbred cows at tropical lower Gangetic region. Vet. World 2020, 13, 2006-2011. [CrossRef] [PubMed]

168. Kolb, E. Seehawer, J. The role of selenium compounds, vitamin E and other factors in the prevention of retained placenta: A review. Tierarztliche Umschau 2002, 57, 666-672.

169. Kamada, H.; Nonaka, I.; Takenouchi, N.; Amari, M. Effects of selenium supplementation on plasma progesterone con-centrations in pregnant heifers. Anim. Sci. J. 2014, 85, 241-246. [CrossRef]

170. Nyman, A.-K.; Emanuelson, U.; Holtenius, K.; Ingvartsen, K.L.; Larsen, T.; Waller, K.P. Metabolites and Immune Variables Associated with Somatic Cell Counts of Primiparous Dairy Cows. J. Dairy Sci. 2008, 91, 2996-3009. [CrossRef]

171. Jukola, E.; Hakkarainen, J.; Saloniemi, H.; Sankari, S. Blood selenium, vitamin E, vitamin A, and $\beta$-carotene concentrations and udder health, fertility treatments, and fertility. J. Dairy Sci. 1996, 79, 838-845. [CrossRef]

172. Dubuc, J.; Duffield, T.; Leslie, K.; Walton, J.; Leblanc, S. Risk factors for postpartum uterine diseases in dairy cows. J. Dairy Sci. 2010, 93, 5764-5771. [CrossRef]

173. Kimura, K.; Goff, J.P.; Kehrli, M.E., Jr.; Reinhardt, T.A. Decreased neutrophil function as a cause of retained placenta in dairy cattle. J. Dairy Sci. 2002, 85, 544-550. [CrossRef]

174. Pontes, G.; Monteiro, P.; Prata, A.; Guardieiro, M.; Pinto, D.; Fernandes, G.; Wiltbank, M.; Santos, J.; Sartori, R. Effect of injectable vitamin $\mathrm{E}$ on incidence of retained fetal membranes and reproductive performance of dairy cows. J. Dairy Sci. 2014, 98, $2437-2449$. [CrossRef] [PubMed]

175. Allison, R.D.; Laven, R.A. Effect of vitamin E supplementation on the health and fertility of dairy cows: A review. Vet. Rec. 2000, 147.

176. Eger, S.; Drori, D.; Kadoori, I.; Miller, N.; Schindler, H. Effects of selenium and vitamin E on incidence of retained placenta. J. Dairy Sci. 1985, 68, 2119-2122. [CrossRef]

177. Bourne, N.; Laven, R.; Wathes, D.C.; Martinez, T.; McGowan, M. A metaanalysis of the effects of vitamin E supplemen-tation on the incidence of retained foetal membranes in dairy cows. Theriogenology 2007, 67, 494-501. [CrossRef] [PubMed] 
178. Leblanc, S.J.; Duffield, T.F.; Leslie, K.E.; Bateman, K.G.; Tenhag, J.; Walton, J.S.; Johnson, W.H. The Effect of Prepartum Injection of Vitamin E on Health in Transition Dairy Cows. J. Dairy Sci. 2002, 85, 1416-1426. [CrossRef]

179. Santos, J.E.P.; Bisinotto, E.S.; Ribeiro, F.S.; Lima, L.F.; Greco, C.R.; Thatcher, W.W. Applying nutrition and physiology to improve reproduction in dairy cattle. Reprod. Domest. Rumin. VII 2010, 67, 387-403. [CrossRef] 